\title{
Phosphorus adsorption in soils under forest and savanna from Northern Amazon, Brazil
}

\section{Adsorção de fósforo em solos sob floresta e savana do Norte Amazônico, Brasil}

\author{
Carlos Henrique de Lima Matos ${ }^{*}$; Valdinar Ferreira Melo²; Sandra Cátia Pereira \\ Uchôa $^{2}$; Pedro Paulo Ramos Ribeiro Nascimento ${ }^{3}$; Raimundo Almeida Pereira ${ }^{1}$
}

\begin{abstract}
Studies on maximum phosphorus adsorption capacity (MPAC) in soils from Roraima State and attributes that interfere with the magnitude of this characteristic are relevant and motivated this study. In this context, topsoil samples $(0-0.20 \mathrm{~m})$ from four soil classes (Oxisol-LA and Oxisol-LV [ITÃ, Caracaraí]; Oxisol-LA [Serra da Prata, Mucajaí]; Oxisol-LA and Ultisol-PA [CCA, Boa Vista]; Oxisol-FT [Bonfim] and Alfisol -SN [Surumu, Pacaraima]) representative of Roraima State were used in this study in order to determine the influence of soil physical, chemical, and mineralogical attributes on MPAC. Air-dried soil samples of $2.5 \mathrm{~g}$ and $0.01 \mathrm{~mol} \mathrm{~L}^{-1} \mathrm{CaCl}_{2}(25 \mathrm{~mL})$ solution were stirred for $24 \mathrm{~h}$, being added $\mathrm{P}$ in the form of $\mathrm{KH}_{2} \mathrm{PO}_{4}$ at concentrations of $0-60,0-80$, and $0-110 \mathrm{mg} \mathrm{L}^{-1}$. P was analyzed in the supernatant for determining its adsorbed amount (P-rem). Adsorption values were fitted to the Langmuir isotherm in order to assess MPAC. Correlation tests were performed between MPAC and binding energy, $\mathrm{pH}$, organic matter, clay, and CEC. MPAC values ranged from 14.50 to $527.93 \mathrm{mg} \mathrm{kg}^{-1}$ in the soil. The soils FT-Bonfim and LV-ITÃ presented a higher MPAC. Considering the representative soil classes in the State, MPAC does not correlate with any of the assessed attributes. In the soil classes Oxisol and Ultisol, MPAC has a negative and significant correlation with binding energy.
\end{abstract}

Key words: Maximum phosphorus adsorption capacity. Correlation. Langmuir isotherm.

\section{Resumo}

Estudos sobre capacidade máxima de adsorção de fósforo (CMAP) em solos de Roraima e atributos que interferem na magnitude dessa característica são relevantes e motivaram esse trabalho. Nesse contexto, amostras da camada superficial $(0-0,20 \mathrm{~m})$ de quatro classes de solos: Latossolo Amarelo LA e Latossolo Vermelho - LV (ITÃ, Caracaraí); Latossolo Amarelo - LA (Serra da Prata, Mucajaí); Latossolo Amarelo - LA e Argissolo Amarelo - PA (CCA, Boa Vista-RR); Plintossolo Argilúvico FT (Bonfim) e Planossolo Nátrico - SN (Surumu, Pacaraima) representativos do estado de Roraima, foram utilizadas no presente trabalho, com a finalidade de determinar a influência de atributos físicos, químicos e da mineralogia dos solos sobre a CMAP. Amostras de 2,5 g de TFSA (terra fina seca ao ar) foram mantidas em contato com soluções de $\mathrm{CaCl}_{2} 0,01 \mathrm{~mol} \mathrm{~L}^{-1}(25 \mathrm{~mL})$, mediante agitação por $24 \mathrm{~h}$, as quais foram adicionados fósforo $(\mathrm{P})$, na forma de $\mathrm{KH}_{2} \mathrm{PO}_{4}$, nas concentrações de 0-60, 0-80 e 0-110 $\mathrm{mg} \mathrm{L}^{-1}$. O P foi analisado no sobrenadante para a determinação da quantidade adsorvida (P-rem). Para avaliar a capacidade máxima de adsorção de fósforo (CMAP), os valores de adsorção foram ajustados à isoterma de Langmuir. Foram realizados testes de correlação entre CMAP e energia de ligação, pH,

\footnotetext{
${ }^{1}$ Profs., Instituto Federal de Roraima, Campus Novo Paraíso, IFRR, Caracaraí, Roraima, Brasil. E-mail: carlos.matos@ifrr.edu.br; ralmeida@ifrr.edu.br

2 Profs., UFRR, Campus Cauamé, Boa Vista, Roraima, Brasil. E-mail: valdinar.melo@ufrr.br; sandra.uchoa@ufrr.br

3 Discente, Curso de Agronomia, UFRR, Campus Cauamé, Boa Vista, Roraima, Brasil. E-mail: pedonpaulo@hotmail.com

* Author for correspondence
} 
matéria orgânica, argila e CTC. Os valores da CMAP situaram-se entre 14,50 e 527,93 mg kg-1 de P no solo. Os solos FT (Bonfim) e LV (ITÃ) apresentaram maior CMAP. Considerando as classes de solos representativas do Estado, a CMAP não se correlaciona com nenhum dos atributos avaliados. Nas classes Latossolo e Argissolo, a CMAP tem correlação negativa e significativa com a energia de ligação.

Palavras-chave: Capacidade máxima de adsorção de fósforo. Correlação. Isotermas de Langmuir.

\section{Introduction}

Soils can work as a source or drain of $\mathrm{P}$ depending on its ability to meet the requirements of plants or compete with them, fixing part of $\mathrm{P}$ added to the soil (NOVAIS et al., 2007). With the increase in the weathering process, soils change from sources to drains due to their increased anion adsorption capacity through positive active sites formed mainly by iron and aluminum oxy-hydroxides (FARIAS et al., 2009).

The use of the Langmuir isotherm has been common in determining these factors since it contains a quantitative parameter related to the maximum phosphorus adsorption capacity (MPAC) and a qualitative parameter that expresses the binding energy between anions and adsorption sites (FARIAS et al., 2009). According to Corrêa et al. (2011), the use of isotherms has two advantages: the first is the ability to estimate $\mathrm{P}$ adsorption attributes and the second is the possibility of knowing the nature of its adsorption processes. This estimation depends on the parent material characteristics, content and mineralogy of clay fraction, the presence of $\mathrm{Fe}$ and $\mathrm{Al}$ oxides, $\mathrm{pH}$, and organic matter (OM) (RANNO, 2007).

One of the factors influencing MPAC in soils is the mineralogy of clay fraction (BERA et al., 2006). According to Fox and Searle (1978), the adsorption process in this fraction can follow the following preferential order: $2: 1$ clays $<1: 1$ clays $<$ crystalline $\mathrm{Fe}$ and $\mathrm{Al}$ oxides $<$ amorphous $\mathrm{Fe}$ and $\mathrm{Al}$ oxides. Minerals that present superficial groupings of $\mathrm{Fe}-$ $\mathrm{OH}$ and $\mathrm{Al}-\mathrm{OH}$ directly influence $\mathrm{P}$ adsorption by means of binder changes (chemisorption), and this adsorption is potentiated by the structural form and contact surface of each mineral (FONTES et al., 2001). Iron and aluminum oxides and kaolinite are responsible for the phenomenon of specific $\mathrm{P}$ adsorption, thus establishing a direct relationship with MPAC (CORRÊA et al., 2011).

In acid soils, Fe and Al oxides increase phosphate adsorption through positive charges formed at acidic $\mathrm{pH}$ or through "bridges" created by the partial bond between oxides and cations such as $\mathrm{Ca}^{2+}$ and $\mathrm{Al}^{3+}$ (NOVAIS et al., 2007). The increase in $\mathrm{Fe}$ and $\mathrm{Al}$ oxides influences MPAC taking into account their concentration and soil acidity (RANNO et al., 2007; PINTO et al., 2013).

There is controversy about the role of $\mathrm{OM}$ in anion adsorption due to its ambivalence. At the same time as $\mathrm{OM}$ provides to the soil positive charges from carboxylic and phenolic radicals at acidic $\mathrm{pH}$, it can also block the active sites of phosphate in the soil by the adsorption of Fe and Al oxides (CHAVES et al., 2007). The reduction of $\mathrm{P}$ adsorption in oxides has been attributed to the action of carbonic acid on the solubilization of P-containing minerals, formation of complexes with humus, increases in the competition between organic anions and phosphate by $\mathrm{P}$ adsorption sites, and formation of humus layers around $\mathrm{Fe}$ and $\mathrm{Al}$ oxides (MOREIRA et al., 2006; NOVAIS et al., 2007; PINTO et al., 2013).

In the Amazon, about $90 \%$ of the soils present high contents of kaolinite and low contents of $\mathrm{Fe}$ and $\mathrm{Al}$ oxides, resulting in a low $\mathrm{P}$ adsorption capacity (SMYTH, 1996). A high MPAC in this region is found in soils with higher contents of clay, free iron, and total iron (MELO et al., 2006). However, the role of kaolinite in $\mathrm{P}$ adsorption should be better investigated since the literature indicates that it may present low or high contents (ROLIM NETO et al., 2004; MOREIRA et al., 2006; BERA et al., 2006). According to Vilar et al. (2010), the importance of 
kaolinite in $\mathrm{P}$ adsorption is related to its degree of crystallinity, in which the adsorption increases with a high crystallinity.

Thus, the aim of this study was to assess the maximum phosphorus adsorption capacity and identify its relationship with soil mineralogical, chemical, and physical attributes representative of Roraima State, Brazil.

\section{Material and Methods}

\section{Sampling sites}

Roraima State has a climate classified as Aw, a rainy tropical climate without a cold season, hot and humid, presenting a well-defined dry (December to March) and rainy (May to August) period according to the Koppen climate classification. According to Barbosa (1997), the average annual temperature is $25^{\circ} \mathrm{C}$ and the average precipitation is $1100 \mathrm{~mm}$ in the northeast region, $1600 \mathrm{~mm}$ in the central region, and $2900 \mathrm{~mm}$ in the southwest region.

In the State's south-central region, particularly in the Itã region, there are developed soils of acidic volcanic rocks (granites/gneisses) that form part of the crystalline basement. From this parent material, yellow hue soils are formed, predominating acid and low-fertility Ultisols and Oxisols (MELO et al., 2010). The reddish soils of the region originate from the Serra da Prata Intrusive Suite, composed of hyperstenius, granites, and gneisses, and Rio Urubu Metamorphic Suite, composed of biotite-gnaisse and metagranitoids; due to the richness of minerals such as biotite and plagioclase, an improvement in soil fertility can be observed (BRASIL, 1998).

The soils of the State's central region are formed from pre-weathered sediments of the Boa Vista Formation accumulated in a shallow basin, dating from the end of the Tertiary and beginning of the Quaternary periods, concomitantly to residual reliefs formed by the Sierras Murupu, Nova Olinda, Serra Grande, Serra da Lua, among others, with kaolinite mineralogy and poor iron oxides associated to granites and gneisses from the Guianense Complex or Basalts of the Apoteri Formation (VALE JÚNIOR; SCHAEFER; COSTA, 2007). Therefore, these soils are acid, with a low fertility, low OM content, low CEC, and a high aluminum saturation (m \%) (MELO et al., 2010; BENEDETTI et al., 2011). The main representative classes of this Formation are Oxisols and Ultisols. The occurrence of residual reliefs from granites and gneisses of the Guianense Complex or Basalts of the Apoteri Formation can also be observed, which are responsible for the red soils occasionally found in the region. The vegetation varies from grassland savanna to park savanna on soils from sediments to forest islands, in inclusions of soils originating from basalt (MELO et al., 2006; VALE JÚNIOR; SCHAEFER, 2010).

In the northern region, the domain of the depression of Surumu, Parimé, and low Cotingo, large patches of Planosols with a high sodium saturation, originating from acidic and intermediate volcanic rocks such as rhyolites, dacites, and riodacites can be found (VALE JÚNIOR et al., 2011). Vegetation presents intrinsic characteristics of the transition from savanna to Caatinga, being common species such as Curatella americana, Byrsonima sp., Cereus, and Melocactus (SCHAEFER et al., 1993).

\section{Selection and collection of soil samples}

Four reference soil classes were selected in the State for conducting the experiment (Table 1). The selection of soil classes was based on their agricultural importance for Roraima State. Profiles of each sampling point were opened and the soils were classified morphologically according to the Manual of Soil Description and Collection (SANTOS et al., 2013). Soil taxonomy was obtained following the criteria of the Brazilian System of Soil Classification (EMBRAPA, 2013). Samples of a depth of 0-0.20 m were collected from each soil class for the analyses and $\mathrm{P}$ adsorption study. At this 
depth, the root system of annual crops presents a greater efficiency. Air-dried soil samples from the different soils were characterized physically and chemically according to Embrapa (1997) (Table 2).

Table 1. Classification and location of seven soils in Roraima State, Brazil.

\begin{tabular}{llll}
\hline \multicolumn{1}{c}{ Soil } & \multicolumn{1}{c}{ Abbreviation } & Municipality & \multicolumn{1}{c}{ Geographical coordinate } \\
\hline $\begin{array}{l}\text { Oxisol (Petroplinthic Dystrophic Yellow } \\
\text { Latosol) }\end{array}$ & LA-ITÃ & Caracaraí & $01^{\circ} 31^{\prime} 36.8^{\prime \prime} \mathrm{N}, 60^{\circ} 45^{\prime} 0.4^{\prime \prime} \mathrm{W}$ \\
$\begin{array}{l}\text { Oxisol (Petroplinthic Dystrophic Red } \\
\text { Latosol) }\end{array}$ & LV-ITÃ & Caracaraí & $01^{\circ} 30^{\prime} 7.1^{\prime \prime} \mathrm{N}, 60^{\circ} 43^{\prime} 13.7^{\prime \prime} \mathrm{W}$ \\
$\begin{array}{l}\text { Oxisol (Typic Dystrophic Yellow Latosol) } \\
\text { Oxisol (Typic Dystrophic Yellow Latosol) }\end{array}$ & LA-Serra da Prata & Mucajaí & $02^{\circ} 22^{\prime} 20.3^{\prime \prime} \mathrm{N}, 60^{\circ} 59^{\prime} 54.0^{\prime \prime} \mathrm{W}$ \\
Ultisol (Typic Dystrophic Yellow Argisol) & PA-CCA & Boa Vista & $02^{\circ} 52^{\prime} 15.9^{\prime \prime} \mathrm{N}, 60^{\circ} 42^{\prime} 40.2^{\prime \prime} \mathrm{W}$ \\
$\begin{array}{l}\text { Oxisol (Abruptic Dystrophic Argiluvic } \\
\text { Plinthosol) }\end{array}$ & FT-Bonfim & Boa Vista & $02^{\circ} 52^{\prime} 22.9^{\prime \prime} \mathrm{N}, 60^{\circ} 42^{\prime} 41.8^{\prime \prime} \mathrm{W}$ \\
Alfisol (Orthic Natric Planosol) & BN-Surumu & $03^{\circ} 32^{\prime} 14.0^{\prime \prime} \mathrm{N}, 60^{\circ} 0^{\prime} 33.3^{\prime \prime} \mathrm{W}$ \\
\hline
\end{tabular}

Table 2. Amplitude of $\mathrm{P}$ doses required for determining the MPAC of seven soils in Roraima State, Brazil.

\begin{tabular}{|c|c|c|c|c|c|c|c|c|c|c|c|}
\hline Interval & \multicolumn{11}{|c|}{ Concentration of P standards } \\
\hline 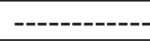 & ---- & ---- & ------ & ------ & $-\mathrm{mg}$ & $-\cdots$ & ---- & ------ & ------ & ----- & ----- \\
\hline \multicolumn{12}{|c|}{ PA-CCA; SN-Surumu } \\
\hline $0-60$ & 0.0 & 3.0 & 6.0 & 9.0 & 15.0 & 21.0 & 27.0 & 33.0 & 42.0 & 51.0 & 60.0 \\
\hline \multicolumn{12}{|c|}{ LA-ITÃ; LV-ITÃ; LA-Serra da Prata; LA-CCA } \\
\hline $0-80$ & 0.0 & 4.0 & 8.0 & 12.0 & 20.0 & 28.0 & 36.0 & 44.0 & 56.0 & 68.0 & 80.0 \\
\hline \multicolumn{12}{|c|}{ FT-Bonfim } \\
\hline $0-110$ & 0.0 & 5.5 & 11.0 & 16.5 & 27.5 & 38.5 & 49.5 & 60.5 & 77.0 & 93.5 & 110.0 \\
\hline
\end{tabular}

Chemical analyses included $\mathrm{pH}$ in water, calcium, magnesium, exchangeable aluminum by means of $1 \mathrm{~mol} \mathrm{~L}{ }^{-1} \mathrm{KCl}$, potassium by means of Mehlich-1; potential acidity by means of $0.5 \mathrm{~mol} \mathrm{~L}^{-1}$ calcium acetate, and $\mathrm{OM}$ determined by oxidation with 0.2 mol L ${ }^{-1}$ potassium dichromate (EMBRAPA, 2009). In addition, particle size distribution was performed by the pipette method (EMBRAPA, 1997) and the textural class of samples was identified by means of a textural triangle proposed by Santos et al. (2013).

Mineralogical analysis of sand, silt, and clay fractions (oriented samples) was performed by $\mathrm{X}$-ray diffraction (XRD). In this process, $100 \mathrm{~mL}$ of water and $10 \mathrm{~mL}$ of $1 \mathrm{~mol} \mathrm{~L}^{-1} \mathrm{NaOH}$ solution were added to $100 \mathrm{~g}$ of the soil sample for dispersing the fractions. After $24 \mathrm{~h}$, samples were submitted to physical dispersion by using a disperser for $10 \mathrm{~min}$. The sand fraction was retained in a $0.053-\mathrm{mm}$ mesh sieve and clay and silt fractions were separated by sedimentation, being washed constantly aiming at removing sodium residues to avoid halite crystal formation, which could interfere with the diffractograms. After sample drying at ambient temperature, soil fractions were macerated and fixed in glass slides with mineral oil for sand and water for silt and clay. Diffractograms were obtained in a Shimadzu diffractometer with a cobalt tube, operating in an interval of 4 to $70^{\circ}$ and a speed of $0.02^{\circ}$ per second. Diffractograms were interpreted according to Chen (1977). 
Maximum phosphorus adsorption capacity (MPAC)

Before quantifying MPAC of each soil, P-rem was determined in solution after $5 \mathrm{~cm}^{3}$ of soil be stirred for $1 \mathrm{~h}$ with $50 \mathrm{~mL}$ of $0.01 \mathrm{~mol} \mathrm{~L}^{-1} \mathrm{CaCl}_{2}$ solution containing $60 \mathrm{mg} \mathrm{L}^{-1} \mathrm{P}$, as Alvarez V. et al. (2000). P-rem values were used to identify adsorption intervals for each soil, reducing the test amplitude and ensuring a greater reliability to the results. Table 2 shows the intervals and $P$ doses used to determine MPAC of the studied soils.

With these intervals, MPAC was determined by using $2.5 \mathrm{~g}$ of soil and $25 \mathrm{~mL}$ of $0.01 \mathrm{~mol} \mathrm{~L}^{-1}$ $\mathrm{CaCl}_{2}$ containing different $\mathrm{P}$ concentrations, as listed in Table 3. These samples were stirred in a horizontal stirrer for $24 \mathrm{~h}$, centrifuged at $3000 \mathrm{rpm}$ for 5 minutes, and filtered (ALVAREZ V. et al., 2000). The equilibrium concentration was used to determine the constants of Langmuir equation, as follows:

$$
\frac{\mathrm{C}}{\frac{\mathrm{x}}{\mathrm{m}}}=\left(\frac{1}{\mathrm{~b}}\right) \times \mathrm{C}+\frac{1}{\mathrm{a} \times \mathrm{b}}
$$

where $\mathrm{C}$ is the $\mathrm{P}$ concentration in the equilibrium solution $\left(\mathrm{mg} \mathrm{L}^{-1}\right), \mathrm{x} / \mathrm{m}$ is the amount of $\mathrm{P}$ adsorbed to the soil ( $\left.\mathrm{mg} \mathrm{g}^{-1}\right)$, a is a constant related to the binding energy of the element to soil $\left(\mathrm{L} \mathrm{mg}^{-1}\right)$, and $b$ is the MPAC of soil. Using this equation, both MPAC and binding energy of $\mathrm{P}$ to soil were estimated.

Table 3. Chemical and mineralogical attributes of seven soils in Roraima State, Brazil.

\begin{tabular}{ccccccccccc}
\hline Soil & $\mathrm{pH}$ & $\mathrm{Ca}$ & $\mathrm{Mg}$ & $\mathrm{K}$ & $\mathrm{Al}$ & $\mathrm{H}+\mathrm{Al}$ & $\mathrm{SB}$ & $\mathrm{CEC}$ & $\mathrm{OM}$ & Mineral \\
\hline LA-IT $\tilde{A}$ & 5.10 & 1.80 & 1.70 & - & 0.20 & 6.40 & 3.50 & 9.90 & 18.40 & $\mathrm{Kt}, \mathrm{Gt}$ \\
LV-ITÃ & 5.40 & 5.40 & 1.90 & 0.50 & 0.20 & 3.00 & 7.80 & 10.80 & 26.30 & $\mathrm{Kt}, \mathrm{Gb}, \mathrm{Gt}, \mathrm{Hm}$ \\
LA-Serra da Prata & 5.60 & 1.80 & 1.00 & - & 0.00 & 3.30 & 2.80 & 6.10 & 11.60 & $\mathrm{Kt}, \mathrm{Gt}$ \\
LA-CCA & 5.10 & 0.10 & 0.10 & 0.10 & 0.10 & 2.90 & 0.30 & 3.20 & 9.20 & $\mathrm{Kt}, \mathrm{Gt}$ \\
PA-CCA & 5.00 & - & - & - & 0.40 & 2.70 & 0.00 & 2.70 & 8.30 & $\mathrm{Kt}$ \\
FT-Bonfim & 5.50 & 2.50 & 0.90 & 0.20 & 0.10 & 1.50 & 3.60 & 5.10 & 15.40 & $\mathrm{Kt}, \mathrm{Gt}, \mathrm{Hm}, \mathrm{Mt}, \mathrm{Mi}$ \\
SN-Surumu & 5.50 & 0.20 & 0.50 & 0.10 & 0.10 & 1.80 & 0.90 & 2.60 & 19.00 & $\mathrm{Kt}, \mathrm{It}$ \\
\hline
\end{tabular}

Kt - Kaolinite; Ep - Expandable minerals; Gb - Gibbsite; Gt - Goethite; Hm - Hematite; It - Illite; Mi - Mica.

\section{Statistical analysis}

Linear correlation studies were performed between MPAC and binding energy, $\mathrm{pH}, \mathrm{OM}$, clay, and CEC for the depth of $0-0.20 \mathrm{~m}$. All parameters were compared by t-test at $5 \%$ probability level and classified according to Larson and Farber (2010).

\section{Results and Discussion}

According to the data showed in Table 3, soils are very acid ( $\mathrm{pH} 5-5.6)$, with values of the sum of bases varying from not detected by the method (PA-CCA) to $7.8 \mathrm{cmol}_{c} \mathrm{dm}^{-3}$ (LV-ITÃ), which is considered very high. In general, soils presented a low exchangeable acidity, except for PA-CCA, which presented a medium value $\left(0.4-1.0 \mathrm{cmol}_{\mathrm{c}}\right.$ $\left.\mathrm{dm}^{-3}\right)$. Regarding potential acidity, soils were classified as high (LA-ITÃ), medium (LV-ITÃ, LA-Serra da Prata, LA-CCA, and PA-CCA), and low (FT-Bonfim and SN-Surumu) (CFSEMG, 1999). OM contents varied from 8.30 to $26.30 \mathrm{~g}$ $\mathrm{kg}^{-1}$ (Table 3). In environments under Cerrado, increments in soil OM is lower than in soils under forest, where the bio cycling of plant material is high and constant (MENDONÇA et al., 2013). For this reason, the highest CEC values occurred in soils under forest (LA-ITÃ and LV-ITÃ).

The clay content of samples varied from 110 to $419 \mathrm{~g} \mathrm{~kg}^{-1}$, with textural classes between sandy and clayey (Table 4). This characteristic influences CEC 
of soils when considering the negative charges from the fraction, in addition to being responsible for generating active sites for $\mathrm{P}$ adsorption via cation bridges (NOVAIS et al., 2007).

Table 4. Physical attributes of seven soils in Roraima State, Brazil.

\begin{tabular}{|c|c|c|c|c|}
\hline \multirow{2}{*}{ Abbreviation } & \multicolumn{3}{|c|}{ Particle size } & \multirow{2}{*}{ Texture } \\
\hline & Sand & Silt & Clay & \\
\hline \multicolumn{5}{|c|}{-------------- $\mathrm{g} \mathrm{kg}^{-1}$-------------- } \\
\hline LA (ITÃ) & 598.50 & 98.80 & 302.70 & Sandy clay loam \\
\hline LV (ITÃ) & 402.20 & 178.40 & 419.40 & Clay \\
\hline LA (Serra da Prata) & 581.30 & 163.60 & 255.10 & Sandy clay loam \\
\hline $\mathrm{LA}(\mathrm{CCA})$ & 640.00 & 97.70 & 262.30 & Sandy clay loam \\
\hline $\mathrm{PA}(\mathrm{CCA})$ & 869.00 & 21.00 & 110.00 & Loamy sand \\
\hline FT (Bonfim) & 588.00 & 290.00 & 122.00 & Sandy loam \\
\hline SN (Surumu) & 760.00 & 120.00 & 120.00 & Sandy loam \\
\hline
\end{tabular}

Clay fraction of LA-ITÃ is predominantly kaolinite with a smaller amount of goethite whereas the clay fraction of LV-ITÃ is composed of kaolinite, gibbsite, goethite, and hematite. The predominance of oxy-hydroxides in LV-ITÃ, together with its more clayey texture, resulted in soils with a higher fertility and CEC when compared to LA-ITÃ (Table 3).

PA-CCA, LA-CCA, and LA-Serra da Prata soils have kaolinite in their clay fractions, occurring goethite in a smaller amount (Table 3). Because of this mineralogy, these soils have a low CEC (MELO et al., 2006; VALE JÚNIOR; SCHAEFER, 2010; BENEDETTI et al., 2011).

Clay fraction of FT-Bonfim is composed of kaolinite, $\mathrm{Fe}$ oxides, and traces of 2: 1 minerals (Table 3). Mica present in this fraction is represented in its totality by muscovite, the most resistant mineral to weathering among those in the mica classes, according to the Bowen series. Therefore, the higher CEC observed for FT-Bonfim among the studied savanna soils might be influenced by the expandable minerals in the clay fraction due to their higher specific adsorption surface when compared to the kaolinite $\left(10-30 \mathrm{~m}^{2} \mathrm{~g}^{-1}\right)$.
For SN-Surumu, clay minerals presented kaolinite with traces of illite. These minerals are commonly found in Planosols of northeastern Roraima (SCHAEFER; DALRYMPLE, 1996), increasing their CEC. However, the predominantly sandy loam texture of this soil has a greater influence on the adsorption power of cations and anions, in addition to presenting the lowest CEC among the studied soils.

The Langmuir isotherms for the studied soils were classified according to MPAC (Figure 1). The linear equations of isotherms, binding energy, MPAC and their correlation with binding energy, $\mathrm{pH}, \mathrm{OM}$, clay, and CEC are shown in Table 5.

Adsorption isotherms presented a high and significant coefficient of determination (Figure 1 and Table 5), demonstrating that the linear equation of Langmuir is adequate in determining the constants of $\mathrm{P}$ adsorption. These isotherms reveal that $\mathrm{P}$ adsorption increases with the concentration of the element in equilibrium solution. Falcão and Silva (2004) and Chaves et al. (2007) obtained similar results in Oxisols and Ultisols in the States of Amazon and Paraíba, which are environments of tropical forest and Atlantic forest, respectively. 
Figure 1. Langmuir adsorption isotherms classified according to MPAC. (A) $0-100 \mathrm{mg} \mathrm{kg}^{-1}$; (B) $100-300 \mathrm{mg} \mathrm{kg}^{-1}$; and $(\mathrm{C})>300 \mathrm{mg} \mathrm{kg}^{-1}$.
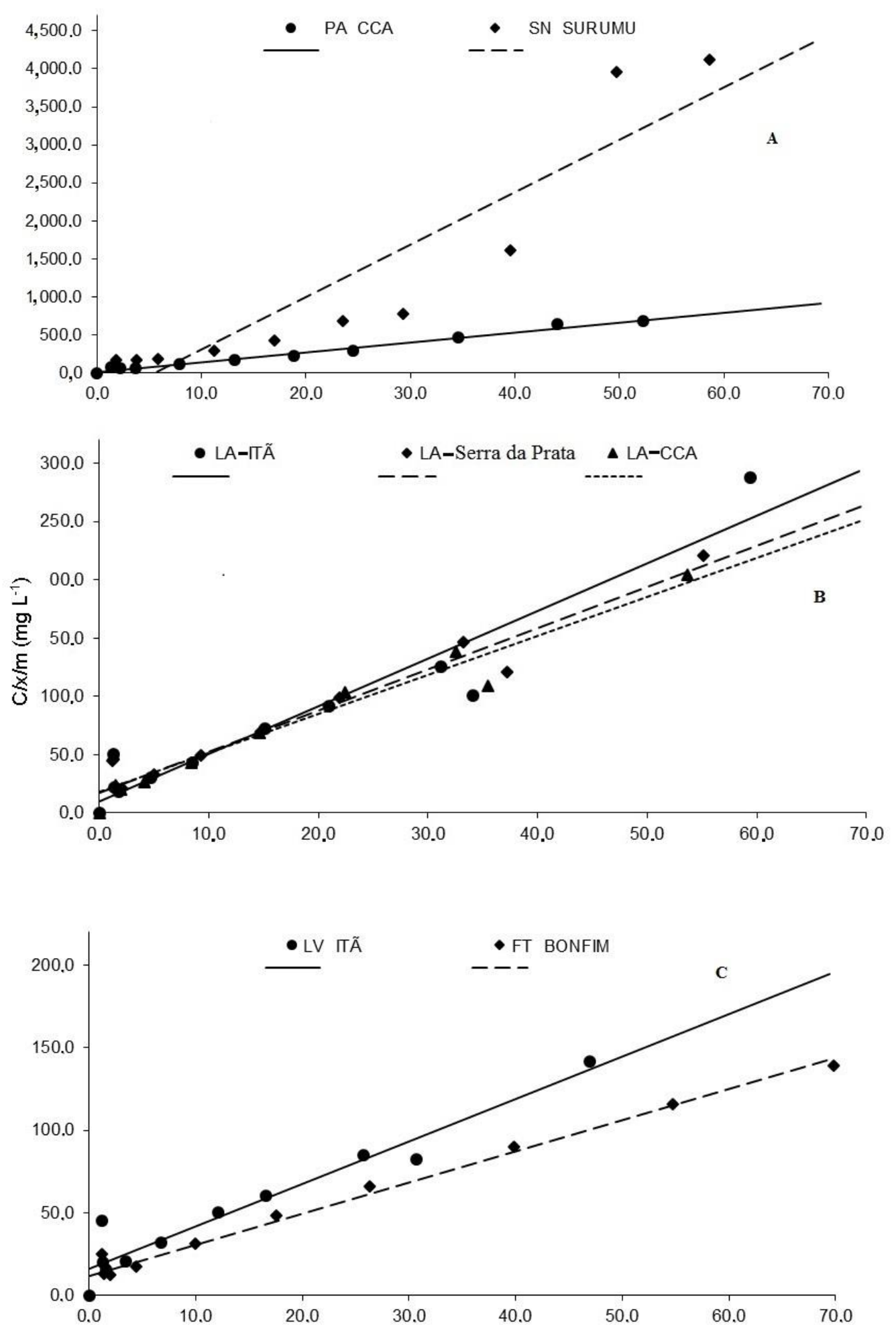
A large amplitude was observed in MPAC, with values ranging from 14.50 and $527.93 \mathrm{~g} \mathrm{~kg}^{-1}$ (Table 5). Soils with a higher adsorption followed the sequence FT-Bonfim $>$ LV-ITÃ $>$ LA-CCA $>$ LASerra da Prata $>$ LA-ITÃ $>$ PA-CCA $>$ SN-Surumu. The main factors that affected the adsorption were texture, mineralogy of clay fraction, OM, and the presence of iron oxides. In spite of the sandy loam texture and savanna environment, FT-Bonfim presented a higher MPAC (527.93 $\left.\mathrm{mg} \mathrm{kg}^{-1}\right)$ due to the diversity of Fe oxides in the clay fraction (Table 3). Clay fraction mineralogy is more important than texture in the availability of active sites for anion adsorption (CUI; WING, 2013; PALÁGYI et al., 2013). Chaves et al. (2007) concluded that, in soils of similar texture, MPAC is influenced mainly by clay mineralogy.

The highest MPAC was observed in LV-ITÃ (389.20 $\mathrm{mg} \mathrm{kg}^{-1}$ ) (Table 5) due to its clayey texture and presence of iron and aluminum oxides. The presence of these oxides generates $\mathrm{pH}$ dependent charges that may be positive. At an acid $\mathrm{pH}, \mathrm{H}^{+}$ ions in solution tend to bind with the hydroxyls of these minerals, generating positive charges that act as active sites for anions (NOVAIS et al., 2007). At a high $\mathrm{pH}$, cations with a higher valence in the soil, mainly $\mathrm{Ca}^{2+}$ and $\mathrm{Al}^{3+}$, can act as "bridges" between oxides and anions. This high adsorption is common in weathered soils, standing out the Oxisols (FALCÃO; SILVA, 2004; CHAVES et al. 2007; FARIAS et al., 2009; CORRÊA et al., 2011).

Oxisols presented a low variation for MPAC values (Table 5), which is due to the texture and mineralogy. We expected that the higher OM and clay contents would determine a higher MPAC in LA-ITÃ, but it did not occur. This is possibly due to the effect of $\mathrm{OM}$ on blocking active sites of $\mathrm{P}$ adsorption, either by increasing the competition between organic anions and phosphate for sites of $\mathrm{P}$ adsorption or by the formation of humus layers around Fe and Al oxides (MOREIRA et al., 2006; NOVAIS et al., 2007; PINTO et al., 2013).

The lowest MPAC values were found in the soils PA-CCA and SN-Surumu (Table 5), which have specific conditions to explain the low anion adsorption such as a low clay and organic matter content and kaolinitic mineralogy. Although presenting a sandy loam texture, FT-Bonfim showed the highest MPAC (Table 5). The oxidic mineralogy, with the occurrence of goethite and hematite, favors a specific $\mathrm{P}$ adsorption and has a direct relation with MPAC (CORRÊA et al., 2011). Despite the low clay content, studies indicate that the ability of iron oxides to adsorb $\mathrm{P}$ is more a function of the specific surface area than of their abundance (BOORGARD, 1983).

Table 5. Coefficients of Langmuir equation, MPAC, binding energy, and the correlation between MPAC and soil attributes $(0-0.20 \mathrm{~m})$.

\begin{tabular}{cccccc}
\hline Soil & \multicolumn{2}{c}{ Langmuir equation } & \multirow{2}{*}{$\mathrm{R}^{2}$} & MPAC & \multirow{2}{*}{ Binding energy } \\
\hline & $\mathrm{C} /(\mathrm{x} / \mathrm{m})=\mathrm{A} \times \mathrm{C}+\mathrm{B}$ & $\mathrm{B}$ & & $\mathrm{g} \mathrm{kg}^{-1}$ & $\mathrm{~L} \mathrm{mg}^{-1}$ \\
LA-ITÃ & 4.09 & 10.16 & $0.92^{*}$ & 244.74 & 0.4023 \\
LV-ITÃ & 2.57 & 16.11 & $0.93^{*}$ & 389.20 & 0.1595 \\
LA-Serra da Prata & 3.54 & 16.91 & $0.96^{*}$ & 282.77 & 0.2091 \\
LA-CCA & 3.35 & 17.84 & $0.94^{*}$ & 298.72 & 0.1876 \\
PA-CCA & 12.95 & 15.40 & $0.98^{* *}$ & 77.24 & 0.8405 \\
FT-Bonfim & 1.89 & 11.68 & $0.98^{* *}$ & 527.93 & 0.1621 \\
SN-Surumu & 68.97 & 379.99 & $0.86^{*}$ & 14.50 & 0.1815 \\
\hline
\end{tabular}

ns, ${ }^{*}, * *-$ not significant $(P>0.05)$, significant $(P \leq 0.05)$, and significant $(P \leq 0.01)$, respectively. 
In spite of the variation in MPAC of the studied soils, $\mathrm{P}$ content is naturally low in most of the soils of Roraima State, as verified in Inceptsol Cambisols, Mollisol Chernosols, and Alfisol Nitosols from northeastern (MELO et al., 2010), Oxisols and Ultisols from the central region (VALE JÚNIOR; SCHAEFER, 2010; BENEDETTI et al., 2011), and Neosols and Spodosols from Southern State (MENDONÇA et al., 2013).

Binding energy varied among soils, following the diversity of attributes, being more expressive in PA-CCA and LA-ITÃ (Table 5). In general, negative charges from clay repel phosphate ions, reducing binding energy. In terms of $\mathrm{OM}$ and oxides, their influences vary according to $\mathrm{OM}$ quality, texture, the amount of oxy-hydroxides, $\mathrm{pH}$, and base saturation. The set of these attributes defines the appearance of negative charges, which, consequently, considerably reduce the binding energy of anions, particularly phosphates. Falcão and Silva (2004) observed the influence of clay and base saturation contents in the decrease of this energy.

No significant correlations were found between MPAC and binding energy, $\mathrm{pH}, \mathrm{OM}$, clay, and CEC (Table 6), disagreeing from the literature (CHAVES et al., 2007; RANNO et al., 2007; FARIAS et al., 2009). The pedological diversity of Roraima (VALE JÚNIOR et al., 2011), resulting from the weathering affected mainly by rainfall variability $(2900 \mathrm{~mm}$ in the south and $1100 \mathrm{~mm}$ in the northern end) (BARBOSA, 1997) and different parent materials such as acidic (rhyolites and granites) and basic volcanic rocks (basalts), in addition to transported sandy sediments, may justify this absence of correlation.

Table 6. Results of statistical analysis obtained by simple Pearson correlation, where MPAC is the variable correlated with several attributes.

\begin{tabular}{lcccccc}
\hline MPAC & $\begin{array}{c}\text { Number of } \\
\text { observations }\end{array}$ & $\begin{array}{c}\text { Binding } \\
\text { energy }\end{array}$ & $\mathrm{pH}$ & OM & Clay & CEC \\
\hline All & 7 & $-0.505^{\text {ns }}$ & $0.293^{\text {ns }}$ & $0.216^{\text {ns }}$ & $0.370^{\text {ns }}$ & $0.464^{\text {ns }}$ \\
LA and PA & 5 & $-0.954^{*}$ & $0.605^{\text {ns }}$ & $0.673^{\text {ns }}$ & $0.801^{\text {ns }}$ & $0.623^{3^{\mathrm{ss}}}$ \\
\hline
\end{tabular}

ns, ${ }^{* * *}$, not significant $(P>0.05)$, significant $(P \leq 0.05)$, and significant $(P \leq 0.01)$, respectively.

In Roraima State, Oxisols and Ultisols resemble their chemical, physical, and mineralogical characteristics, but differ their textural gradient required for class division. In this sense, when both soils were grouped, a significant and negative correlation between MPAC and binding energy was observed, showing that the binding energy between $\mathrm{P}$ and its active sites decreased due to the repulsion caused by negative charges from clays and oxides. This result is in accordance with Falcão and Silva (2004), Ranno et al. (2007), Farias et al. (2009), and Corrêa et al. (2011).

\section{Conclusions}

Maximum $\mathrm{P}$ adsorption capacity of soils follows the following sequence FT-Bonfim $>$ LV-ITÃ $>$ LA-CCA $>$ LA-Serra da Prata $>$ LA-ITÃ $>$ PA$\mathrm{CCA}>\mathrm{SN}-$ Surumu.

Soils from forest environments present a higher MPAC, except for FT-Bonfim, due to the higher occurrence of iron oxides.

In Oxisols and Ultisols, a negative and significant correlation exists between MPAC and binding energy. 


\section{References}

ALVAREZ, V. V. H.; NOVAIS, R. F.; DIAS, L. E.; OLIVEIRA, J. A. Determinação e uso do fósforo remanescente. Viçosa: SBCS, 2000. 32 p. (Boletim informativo, 25).

BARBOSA, R. I. Distribuição das chuvas em Roraima. In: BARBOSA, R. I.; FERREIRA, E. J. G.; CASTELLÓN, E. G. Homem, ambiente e ecologia no estado de Roraima. Manaus: INPA, 1997. p. 325-335.

BENEDETTI, U. G.; VALE JÚNIOR, J. F.; SCHAEFER, C. E. G. R.; MELO, V. F.; UCHÔA, S. C. P. Gênese, química e mineralogia de solos derivados de sedimentos pliopleistocênicos e de rochas vulcânicas básicas em Roraima, norte Amazônico. Revista Brasileira de Ciência do Solo, Viçosa, v. 35, n. 2, p. 299-312, 2011.

BERA, R.; SEAL, A.; BHATTACHARYYA, P.; K. MUKHOPADHYAY, K.; GIRI, R. Phosphate sorption desorption characteristics of some ferruginous soils of tropical region in Eastern India. Environmental Geology, London, v. 51, n. 3, p. 399-407, 2006.

BRASIL. Programa levantamentos geológicos básicos do Brasil (Roraima Central): carta geológica [mapa]. Córrego Alegre, CPRM, 1998.

BOORGARD, O. K. Effect of surface area and mineralogy of iron oxides on their surface charge and anion-adsorption properties. Clays and Clay Minerals, Chantilly, v. 31, n. 3, p.230-232, 1983.

CHAVES, L. H. G.; CHAVES, I. B.; MENDES, J. S. Adsorção de fósforo em materiais de Latossolo e Argissolo. Revista Catinga, Mossoró, v. 20, n. 3, p. 104111, 2007.

CHEN, P. Y. Table of key by lines in X-ray power diffraction patterns of minerals in clays and associated rocks. Bloomington: Department of Natural Resources Geological Survey, 1977. 67 p.

COMISSÃO DE FERTILIDADE DO SOLO DO ESTADO DE MINAS GERAIS - CFSEMG. Recomendações para o uso de corretivos e fertilizantes em Minas Gerais. 5. ed. Lavras, 1999. 359 p.

CORRÊA, R. M.; NASCIMENTO, C. W. A.; ROCHA, A. T. Adsorção de fósforo em dez solos do estado de Pernambuco e suas relações com parâmetros físicos e químicos. Acta Scientiarum, Maringá, v. 33, n. 1, p. 153159, 2011

CUI, Y.; WENG, L. Arsenate and phosphate adsorption in relation to oxides composition in soils: LCD modeling. Environmental Science and Technology, Berkeley, v. 47, n. 13, p. 7269-7276, 2013. Available at: <http://dx.doi. org/10. 1021/es400526q >. Accessed at: 7 jul. 2017.
EMPRESA BRASILEIRA DE PESQUISA AGROPECUÁRIA - EMBRAPA. Manual de métodos de análises de solo. 2. ed. Rio de Janeiro: CNPS, 1997. $212 \mathrm{p}$.

Manual de análises químicas de solos, plantas e fertilizantes. 2. ed. Brasília: EMBRAPA, 2009. 627 p.

Sistema brasileiro de classificação de solos. 3 . ed. Brasília: EMBRAPA, 2013. 353 p.

FALCÃO, N. P. S.; SILVA, J. R. A. Características de adsorção de fósforo em alguns solos da Amazônia Central. Acta Amazônica, Manaus, v. 34, n. 3, p. 337342, 2004.

FARIAS, D. R.; OLIVEIRA, F. H. T.; SANTOS, D.; ARRUDA, J. A.; HOFFMANN, R. B.; NOVAIS, R. F. Fósforo em solos representativos do estado da Paraíba: Isotermas de adsorção e medidas do fator capacidade de fósforo. Revista Brasileira de Ciência do Solo, Viçosa, v. 33, n. 3, p. 623-632, 2009.

FONTES, M. P. F.; CAMARGO, O. A.; SPOSITO, G. Eletroquímica das partículas coloidais e sua relação com a mineralogia de solos altamente intemperizados. Scientia Agrícola, Piracicaba, v. 28, n. 3, p. 627-646, 2001.

FOX, R. L.; SEARLE, P. G. E. Phosphate adsorption by soils of the tropics. In: DROSDOFF, M. Diversity of soils in the tropics. Madison: American Society of Agronomy, 1978. p. 97-119.

LARSON, R.; FARBER, B. Estatística aplicada. Tradução Luciane Vianna. 4. ed. São Paulo: Pearson, 2010.

MELO, V. F.; SCHAEFER, C. E. G. R.; FONTES, L. E. F.; CHAGAS, A. C.; LEMOS JÚNIOR, J. B.; ANDRADE, R. P. Caracterização física, química e mineralógica de solos da colônia agrícola do Apiaú (Roraima, Amazônia), sob diferentes usos e após queima. Revista Brasileira de Ciência do Solo, Viçosa, v. 30, n. 6, p. 1039-1050, 2006.

MELO, V. F.; SCHAEFER, C. E. G. R.; FONTES, L. E. F.; CHAGAS, A. C.; LEMOS JÚNIOR, J. B.; ANDRADE, R. P. Solos da área indígena Yanomami no médio Rio Catrimani, Roraima. Revista Brasileira de Ciência do Solo, Viçosa, v. 34, n. 2, p. 487-496, 2010.

MELO, V. F.; SCHAEFER, C. E. G. R.; UCHÔA, S. C. P. Indian land use in the Raposa-Serra do Sol Reserve, Roraima, Amazonia, Brazil: physical and chemical attributes of a soil catena developed from mafic rocks under shifting cultivation. Catena, Amsterdam, v. 80, n. 2, p. 95-105, 2010.

MENDONÇA, B. A. F.; FERNANDES FILHO, E. I.; SCHAEFER, C. E. G. R.; SIMAS, F. N. B.; VALE 
JÚNIOR, J. F.; LISBOA, B. A. R.; MENDONÇA, J. G. F. Solos e geoambientes do Parque Nacional do Viruá e entorno, Roraima: visão integrada da paisagem e serviço ambiental. Ciência Florestal, Santa Maria, v. 23, n. 2, p. 429-444, 2013.

MOREIRA, F. L. M.; MOTA, F. O. B.; CLEMENTE, C. A.; AZEVEDO, B. M.; BOMFIM, G. V. Adsorção de fósforo em solos do Estado do Ceará. Revista Ciência Agronômica, Fortaleza, v. 37, n. 1, p. 7-12, 2006.

NOVAIS, R. F.; SMYTH, T. J.; NUNES, F. N. Fósforo. In: NOVAIS, R. F.; ALVAREZ V., V. H.; BARROS, N. F.; FONTES, R. L. F.; CANTARUTTI, R. B.; NEVES, J. C. L. Fertilidade do solo. Viçosa, MG: SBCS, 2007. p. 471-550.

PALÁGYI, Š.; ŠTAMBERG, K.; HAVLOVÁ, V.; VODIČKOVÁ, H. Effect of grain size on the Sr sorption and desorption in columns of crushed granite and infill materials from granitic water under dynamic conditions. Journal of Radioanalytical and Nuclear Chemistry, London, v. 297, n. 1, p. 33-39. 2013.

PINTO, F. A.; SOUZA, E. D. de; PAULINO, H. B.; CURI, N.; CARNEIRO, M. A. C. P-sorption and desorption in savanna brazilian soils as a support for phosphorus fertilizer management. Ciência e Agrotecnologia, Lavras, v. 37, n. 6, p. 521-530, 2013.

RANNO, S. K.; SILVA, L. S.; GATIBONI, L. C.; RHODEN, A. C. Capacidade de adsorção de fósforo em solos de várzea do estado do Rio Grande do Sul. Revista Brasileira de Ciência do Solo, Viçosa, v. 31, n. 1, p. 2128, 2007.

ROLIM NETO, F. C.; SCHAEFER, C. E. G. R.; COSTA, L. M.; CORRÊA, M. M.; FERNANDES FILHO, E. I.; IBRAIMO, M. M. Adsorção de fósforo, superfície específica e atributos mineralógicos em solos desenvolvidos de rochas vulcânicas do Alto Paranaíba, Minas Gerais. Revista Brasileira de Ciência do Solo, Viçosa, v. 28, n. 6, p. 953-964, 2004.
SANTOS, R. D.; LEMOS, R. C.; SANTOS, H. G.; KER, J. C.; ANJOS, L. H. C.; SHIMIZU, S. H. Manual de descrição e coleta de solo no campo. 6. ed. Viçosa: SBCS, 2013. 100 p.

SCHAEFER, C. E. G. R.; DALRYMPLE, J. Pedogenesis and relict properties of soils with columnar structure from Roraima, north Amazonia. Geoderma, Amsterdam, v. 71, n. 1, p. 1-17, 1996.

SCHAEFER, C. E. G. R.; REZENDE, S. B.; CORRÊA, G. F.; LANI, J. L. Características químicas e pedogênese de solos afetados por sódio do nordeste de Roraima. Revista Brasileira de Ciência do Solo, Viçosa, v. 17, n. 3, p. 431-438, 1993.

SMYTH, T. J. Manejo da Fertilidade do Solo para produção Sustentada de Cultivos na Amazônia. In: ALVAREZ V., V. H.; FONTES, L. E. F.; FONTES, M. P. F. O solo nos grandes domínios morfoclimáticos do Brasil e o desenvolvimento sustentado. Viçosa: SBCS, 1996. p.71-93.

VALE JÚNIOR, J. F.; SCHAEFER, C. E. G. R. Etnopedologia e transferência de conhecimento: diálogos entre os saberes indígena e técnico na terra indígena malacacheta. Revista Brasileira de Ciência do Solo, Viçosa, v. 31, n. 2, p. 403-412, 2007.

. Solos sob Savanas de Roraima: gênese, classificação e relações ambientais. Gráfica Ioris, Boa Vista, 2010. 219 p.

VALE JÚNIOR, J. F.; SOUZA, M. I. L.; NASCIMENTO, P. P. R. R.; CRUZ, D. L. de S. Solos da Amazônia: etnopedologia e desenvolvimento sustentável. Revista Agroambiente, Boa Vista, v. 5, n. 2, p. 158-165, 2011.

VILAR, C. C.; COSTA, A. C. S. da; HOEPERS, A.; SOUZA JÚNIOR, I. G. de. Capacidade Máxima de Adsorção de Fósforo relacionada a formas de ferro e alumínio em solos Subtropicais. Revista Brasileira de Ciência do Solo, Viçosa, v. 34, n. 4, p. 1059-1068, 2010. 
